\title{
TRANSLATION AND REWRITING \\ OF SIBYLLINE PROPHECIES: \\ THE CASE OF JANE SEAGER
}

\author{
Carme Font Paz \\ Universitat Autònoma de Barcelona \\ Carme.Font@uab.cat
}

The tradition of evoking the prophecies of the Sibyls was not uncommon in late medieval Europe: their prediction of the birth of Christ turned them into uncompromising figures of a pre-Christian mythical tradition that was not at odds with any aspect of the Catholic mentality. Their iconographic representation had been established earlier on through Raphael's and Botticelli's mythographic approaches, as well as by the work of the humanist scholars at Cardinal Giordano Orsini's court in Rome, where around the I430s the classical set of ten sibylline figures was increased to twelve. The Sibyl's verses also appeared in the mystery plays at Chester in the early fifteenth century, and as captions to Baccio Baldini's engravings of the twelve prophetesses in the I470s, where they were richly adorned as dignified figures. More than a century later, and in a totally different environment, the English Tudor court, the sibylline imagery might have lost its intriguing cult to the vernacular or its strong Neo-platonic foundation, but poets such as Thomas Wyatt, and Philip Sidney in particular in his The Defence of Poesy (1579), invoked the Sybils as muses and patronesses of the arts. Within the post-Petrarchan appropriation and translation of Italian verse by some of the best practitioners of Elizabethan poetry, there was a discreet and feminine current of translatio to which some women (daughters, sisters or wives of humanist scholars) would eagerly subscribe. Such was the case of Jane Seager, the sister of William Segar (note the vowel change in the surname) who was a herald and portrait-painter of repute.

The only known work by Jane Seager is a manuscript entitled The Divine Prophesies of the Ten Sibills which is held in the British Library (MS I0037) and dated in 1589. The timing coincides with Sidney's writing and circulation of his Defence prior to his posthumous publication in 1595 . As we shall see, Seager's appropriation of the meaning and the image of the Sibyl is closer to its Italian Quattrocento leanings for its emphasis on visual representation and reverence to 
artistic detail. Such a work was intended as a gift book to queen Elizabeth, and it has textual and artistic interest. Seager defined herself as a "Mayden", and in this very especial present to Elizabeth I she adopts the role of the friend and admirer who devotes considerable time and skill to produce an object d'art for both personal and public consumption. Seager translates the prophecies of the ten Sibyls related to the birth and mission of Christ, and literally frames these poems in a preface and a series of concluding remarks. The elegant wording of the manuscript is shown in the italic calligraphy on vellum and margins trimmed in gold. They contain ten of the twelve Sibyline prophesies about Christ, translated by Seager herself from the Latin of Filippo Barbieri's Sibyllarum de Christo Vaticina in the fifteenth century.

The fact that Seager used Barbieri's edition as a source text reveals an interest in the aesthetics of the Quattrocento as well as a modernization or a revalidation of the sibylline cult devoid of its high medieval representations. The English translation of each prophetic utterance is reproduced on the left-hand (verso) page in neat italic script, while on the right (recto) page the poem is mirrored in shorthand form. The physician and clergyman Timothe Bright had devised a shorthand system around 1550, described in his book Characterie An Arte of Shorte, Swifte, And Secrete Writing by Character. Seager's appropriation and intermingling of the humanist tradition of translation, the Italianized taste for luxury and the long-standing tradition of female prophesy can only find expression in Elizabethan material culture: the commemorative purpose of the gift, though, does not detract from its quality as a translated text, and his lavish velvety presence does not trivialize its content. Thus literature becomes an object of visual delight and personal meditation in a typical Elizabethan fashion in which private matters become state affairs. Even though Seager did not make explicit the reason why she includes shorthand symbols in her text (her brother did not include them in his writings), the strange symbols seem to evoke an ancient runic graphic effect. The extreme care with which this translator-author-craftswoman approaches her creation reveals a special sensibility for beauty. It may as well serve a more practical purpose by suggesting a secret code for the queen to use in her correspondence; even though such a "hint" to queen Elizabeth cannot be proved, Deirdre Serjeantson mentions a brief but significant acquaintance between William Segar and Francis Walsingham, which may have triggered an interest in secret codes and writing. At the same time, and in keeping with the prophetic tradition of The Book of Daniel, the shorthand symbols resemble the 'writing on the wall'. In every one of these processes, Seager's expertise as an artist and as an apt translator reflect an unusual kind of originality: while most gift-books to queen Elizabeth were bound by and attached to needlework covers, Seager surpasses her fellow 
would-be courtiers with her prodigal cover. She contrives her role as a translator by opening up a space for an original literary contribution that goes beyond the rendering of a classical text into a "vernacular" language: here, through the language of femininity, she strives to make her voice and talents known within the discourse of prophecy.

Since the beginning of the sixteenth century, women in England had already been exposed to a religious discourse that invited them to express themselves in writing. Humanism had championed the education of females, and although in actual practice it excluded them from formal and higher education, it allowed women from large sections of the middle and upper classes to become familiar with the Bible and the Psalms. For most women, access to Protestant spirituality occurred initially through oral means; it was only gradually that the study of Scripture at home and in parish gatherings made women more proficient in reading the sacred texts and commenting on them. Close contact and familiarity with the Bible, whether in oral or in written form, was by no means prohibited to women, but was in fact encouraged by the predominant cultural context. Most cultural historians of the Reformation ${ }^{\mathrm{I}}$ are of the opinion that religion was itself gendered, and that men and women expressed it differently through their use of language and their social habits. In this regard, the practice of piety and charity epitomized the highest ideal of the religious woman, particularly in the middle and elite classes: since women were believed to be emotional and more susceptible to holiness, it was regarded as a space of virtue in which they could excel. Some took their works of piety and charity as duties but also as a possibility of reinforcing their self-esteem, since these gave them a sense of fulfilment and integration in the community. Acts of charity, in a strictly Protestant context inside or outside the court, cannot be pinpointed as a key to personal salvation, since grace - in both the Lutheran and later on Calvinist traditions - runs independently from the actions of men and women; still, the practice of good deeds had retained its prestige since the days of Catholicism. Diane Willen reminds us of its social function and the fact that generous acts, "suggested spiritual egalitarianism, since, despite the patriarchal nature of church and society, it could be a source of self-expression and of influence" (Willen, 2002, p. 22).

Jane Seager and her learned women from Elizabethan circles tended to relate acts of piety, generosity and devotion with the endorsement or acceptance of their activity from the court. Seager resorts neither to the Old nor the New Testament, but to a pre-Biblical tradition that foreshadows a virtuous cult of femi-

I For a historical appreciation of gender and religion in sixteenth-century England, see Beilin, 1987; Collinson, 1992; Haigh, I993; Hamilton and Strier, I996; Ruether, I990; Todd, 1995; Trill, 1996; and Wiesner, 1993. 
ninity devoid of controversial theological stances. Her generosity and deferential approach to the Queen evokes a prophetic classic tradition that situates the prophet in a position of strong individual prominence, and sets her before the general public as a significant exception, isolated in her reception and projection of the voice of the Spirit. Through an exercise of adapting Latin inscriptions into the vernacular Seager is not simply establishing her reputation as a translator from a humanist scriptorium, she is grounding a model of communication taking place only between females, since in her preface she specifically associates the sibylline birth of Christ with the good omen of Elizabeth's reign. Seager is not only wishing Queen Elizabeth well, or praising her sensible rule: through a lavish exhibition of her own talents, she is making a public announcement in which she prophesies the good standing and moral excellence of her Queen.

The assumption of a prophetic function could entail as many challenges as advantages: by definition, a prophet must necessarily speak from outside the dominant institutions -irrespective of the support he/she might receive from her own circle - and from a position of moral superiority over them. Old Testament prophets advocate for a particular way of living or an ethical position; although that position can vary from prophet to prophet and to their specific social circumstances, the common element binding them all is their defence of and respect for the Law of God, and their presentation of that Law as the necessary basis for the establishment or improvement of the political system. Among these classical prophets, we find oracles denouncing the sin and apostasy of Israel and Judah in books such as Isaiah, Jeremiah, Amos, and Hosea, all of which include visions or predictions of national doom usually at the hands of foreign powers; they customarily attribute this impending disaster to the sins of the community they speak to, urging the faithful to repent before it is too late. On the other hand, the attitude of the prophet is always oriented towards the justification of God's wrath and his long-term designs for humanity: The dire warnings that the prophets offer are generally coupled with their faith in an apocalyptic future, in which God's justice will have been fully implemented. This implies a full conviction of the righteousness of God's ways and a willingness to justify them before an audience that is often uncomprehending or unresponsive. As John Barton has remarked,

One chief concern of the prophets is theodicy, the justification of God's ways with his world. In the interests of a coherent theodicy, great rhetorical skill is needed to be employed. Even if we can hardly avoid questioning the prophets' theology, we are bound to admire their literary talent (Barton, I990, p. 52). 
Jane Seager's prophetic stance is unusual in using the Sibyls as a model of female authority that endorses the acts and moral standard of another female (Elizabeth I). The actual integration of the sibylline tradition, coming from the different editions of the oracles that might have been available to Seager, is also a revealing aspect of this gift-work. Deirdree Serjeantson argues that the earliest extant collection of sibylline prophecies within the Christian Tradition was that of the church father Lactantius in his Divine Institutes of $c$. 310; this text was designed as an apologetic work to counteract pagan currents and in order to do so Lactantius invokes classical sources. By citing ten sibyls from a 'lost book' by Marcus Varro, he seeks to demonstrate that pre-Christian women prophets encouraged belief in one and only God that rewards virtue. But Jane Seager's gives the sibylline cult a more modern, directly contemporary slant:
(Agrippa:)
The highest birth shallbe under the fleshe
A Virgine trew without all spot, or blame.
The sacred worde shall fill with heavenly grace
By the prescience of the holy spirit.
And notwithstanding that shee shall bring forth
The only surety of our saving health,
Who on his back shall carry all our synnes;
Yet shall he ne despised of the world,
Whose constant honor, love and glorye sure,
Shall from all ages to all age indure.
An ${ }^{\circ}$ Mundj. 2720 2 .

In this fragment, Seager's translation of Agrippa (sometimes known as Egyptia), the holy spirit sacralises the word of the Sibyl and redeems our sins. Notice the denomination of "holy spirit" and not the usual Verstegan-like allusions to the muses of any symbolism of light as representing the triumph of good over evil. If the images of the sibyls were a common sight in pre-Reformation England, Seager's translation of Barbieri's Sibyllarum prefigures in her choice of vocabulary a more 'modern' and 'reformed' understanding of the spirit as a redeeming force that is originated from and directed to a model of female virtue. Thus Seager's gift invites the Queen to enter some form of reciprocity with her by drawing on contemporary ideals on women. The imposing presence of the book exhibits her skills as a craftswoman, while the subject matter is an exercise in translation.

2 The date given to the Sibyl prophecy was meant to correspond with the number of years elapsed since the creation of the world, according to the chronology of Marcus Varro on Roman history (II6-27 b.C.). 
There exists no written acknowledgment of receipt nor any compliment on the part of Queen Elizabeth, and hence there is no guarantee that she actually read and enjoyed Seagar's gift. It is most likely that Seager did not feel discouraged by this probable silence, since she adopts a very humble stance since the beginning about her work,

Sacred $\mathrm{Ma}^{\text {ty }}$ Maye yt please those most gracious eyën (acquaynted with all perfections, and above others Most Excellent) to vouchsafe to make worthy of their princely view, the handy-worke of a Mayden your $\mathrm{Ma}^{\text {ties }}$ most faithful Subject ( 589 , preface)

Seager resorts to a rhetorical device that is characteristic of many printed dedications and book prefaces in the Elizabethan context: that of debasing oneself and one's work as an act of virtual surrender to the Queen. Seager is perfectly aware that she is reproducing a generic form, but at the same time she is able to establish a direct single-line of communication with her addressee by suggesting a renewed association between the Queen and herself as a prophet: the Sibyls become purveyors of an ancient albeit modernized tradition, by dint of Seager's role as an author-translator-craftsmaker. As she argues in her preface,
It conteyneth (Renomed Sovereigne)
the divine prophesies of the ten Sibills (virgyns)
upon the birthe of our Saviour Christ,
by a most blessed virgin; of $\mathrm{w}^{\text {ich }}$ most holy faith, your
$\mathrm{Ma}^{\text {ty }}$ being cheife Defendress, and a virgyn also, yt is
A thinge (as it weare) preordeyned of god, that this
Treatis, wyrtten by a Mayden your Subject, should be
Only devoted unto your most sacred selfe (I89).

These lines hint at the fact that the Queen, as defender of the faith, symbolically has become the Sibylline Last Emperor of old. Seager then makes a series of assumptions: that Elizabeth, the mother of Christ, and the Sibyls were all virgins; she herself, as a virgin, is preordained by the gods to present these poems to Elizabeth. Thus Seager seeks to establish a direct rapport with Elizabeth, a bond based on their shared virginity and its divine quality.

Jessica L. Malay argues that the actual placement and translation of the poems foreground the divine nature of that virginity (p. I28). The source text, Filippo Barbieri's fifteenth-century Sibyllarum, was included in Xystus Betuleius's I545 edition of The Sibylline Oracles. It was included as well in Sebastian Castellio's I555 edition of these oracles, the Sibyllinorum Oraculorum Libri VIII. This, 
according to Malay, would have been the edition most accessible for Seager. She organizes her poems in such a way that she can communicate an eschatological discourse placing Queen Elizabeth at its focus. She begins the series with Sibyl Agrippa, marking the date of her prophecy as 2720 . A. M. The poem introduces the "virgine trew without all spot, or blame"(I89), and states that this virgin will be the conduit through which salvation will be able to enter the world. This first poem refers to the birth of Christ, but the references connecting Elizabeth with a Last Emperor preparing the world for the second coming of Christ are noticeable.

The second poem, a prophecy by the Sibyl Samia, elaborates on this subject with her prophecy of a "cheerful days shall shortly come" even though the offices of a "virgine most inviolate". In Seager's verse prophecy of the Sibyl Europea, she provides a transition from texts which announce the coming of Christ to a defence of his divine message. Here the power of the word, or the gospel, is presented:

Th'eternall word shall come from heaven aboce

And shall inspire the body of a mayd,

Conceaving by the eare a blessed babe (I9I).

The poem continues with lines alluding to her role as promoter of the Gospel -as her mother Anne Boleyn did-and intend to represent Elizabeth as Christlike:

Who not withstanding being sent from heaven

Shall come into ye world simple and poore,

And shall rule all things with a Quyer raign (19I).

In the end, it is asserted that this prince "shalbe half divine, and humanye seed"; Seager is obviously drawing upon contemporary discourses surrounding the Queen and her court. Actually, Edmund Spenser in his April eclogue, also alluded to Elizabeth's birth as a divine circumstance:

For shee is Syrinx daughter without spotte

Which Pan, the shepheards god, of her begot

So sprong her grace

Of heavenly race,

No mortall blemishe may her blotte?.

At the same time, Seager's Sibyl Delphica reinforces the role of a divinely appointed virgin in God's eschatological plan: 
Of a pure virgine; without helpe of man,

Shall come for the to the woerld, and sgall exceed

All other works which ever nature wrought:

But hee that ruleth all thinges under sonne,

Hath by his power ordained yt to be done (192).

Seager finished the collection in the same way that she started it: transforming the imagery and symbolism in Barbieri's Latin Sibylline prophecies of Christ into a powerful tribute to Queen Elizabeth. The abundant references to a blessed virgin and a just ruler fit neatly into contemporary imagery developing around the Queen in the late 1580 os. Her translation accentuates Barbieri's imagery removing it from its fifteenth-century context, in order to position Elizabeth in a preeminent place within an eschatological framework. Thus her gift book serves to present Elizabeth as an emperatrix of renown, and a last one for that; she is also a Marian figure with Christic leanings. Her catalogue-like description of the Sibyls are a "meta-textual acknowledgment that this gift book is simply participating in the courtly discourse of praise" (Malay, 20IO, p. 136), but in her very last lines of her preface Seager acknowledges that she cannot empower these Sibylline texts to actually define and uplift the Queen: after all, she cannot "become" that "which worlds with wounder might define". This apparent inability to exactly accommodate the sibylline elements in a gender-codified context does not exhaust the prophetic stance in sixteenth-century court poetry. Seager's case illustrates an appropriation of a medieval tradition that translates (and is translated) by women actively working in humanistic scriptoria, who sought to integrate some aspects belonging to the artistic tradition of the late medieval Quattrocento within an early Protestant sensibility and discourse.

\section{BIBLIOGRAPHY}

Barton, J., 1990: "History and Rhetoric in the Prophets", in M. Warner (ed.) The Bible as Rhetoric: Studies in Biblical Persuasion and Credibility, London, pp. 5I-64.

Beilin, E., 1987: Redeeming Eve: Women Writers of the English Renaissance, Princeton.

Collinson, P., 1992: The Birthpangs of Protestant England: Religious and Cultural Change in the Sixteenth and Seventeenth Centuries, London.

Dempsey, Ch., 2012: The Early Renaissance and Vernacular Culture: The Bernard Berenson Lectures on the Italian Renaissance, Cambridge-Masachussets. Haigh, C., 1993: English Reformations: Religion, Politics, and Society, Oxford. 
Hamilton, D. B., and Strier, R. (eds.), 1996: Religion, Literature and Politics in Post-Reformation England, Cambridge.

Malay, J. L., 2010: "To be a Sibyl", in Prophecy and Sibylline Imagery in the Renaissance, Routledge, London, pp. I2I-I36.

Millman, J. S., and Wright, G. (eds.), 2005: Early Modern Women's Manuscript Poetry, Manchester.

Ruether, R. R., 1990: Prophets and Humanists: Types of Religious Feminism in Stuart England, London.

Seager, J., 2006: The Divine Prophesies of the Ten Sibills. J. L. Malay (ed.), English Literary Renaissance, 36:2, pp. I89-193.

Serjeantson, D., 2013: "Translation, Authorship, and Gender: The Case of the Jane Seager's Divine Prophecies of the Ten Sibills", in G. Schmidt (ed.), Elizabethan Translation and Literary Culture, Berlin, pp. 227-254.

Sidney, Ph., 2004 [1579]: The Defence of Poesy, G. Alexander (ed.), London.

Spenser, E., 1999: The Shorter Poems, R. Mccabe (ed.), London.

Todd, M., 1995: Reformation to Revolution: Politics and Religion in Early Modern England, London

Trill, S., 1996: Religion and the Construction of Femininity, Cambridge.

Wiesner, M. E., 1993: Women and Gender in Early Modern Europe, Cambridge.

Willen, D., 2002: "Religion and the Construction of the Feminine", in A. Pacheco (ed.), The Companion to Early Modern Women's Writing, London: pp. 22-40. 
